\title{
Quantitative culture of Helicobacter pylori from gastric juice: the potential for transmission
}

\author{
K. A. YOUNG, Y. AKYON, D. S. RAMPTON*, S. G. R. G. BARTON*, R. P. ALLAKER, J. M. HARDIE \\ and R. A. FELDMAN† \\ Department of Oral Microbiology, * Gastrointestinal Science Research Unit and $\uparrow$ Department of Epidemiology \\ and Medical Statistics, St Bartholomew's and the Royal London School of Medicine and Dentistry, London, \\ E1 $2 A D$
}

\begin{abstract}
The transmission of Helicobacter pylori may occur by spread of organisms from gastric juice which has been introduced into the mouth by gastro-oesophageal reflux. The aim of this study was to quantify the load of $\mathrm{H}$. pylori present in gastric juice available for transmission. Gastric antral biopsy and gastric juice samples were collected from 108 adult dyspeptic patients undergoing routine upper gastroscopy and the presence of $\boldsymbol{H}$. pylori was determined. In all, $54(50 \%)$ of 108 patients gave positive results in the gastric antral biopsy rapid urease test and for $H$. pylori histology. The gastric juice of $40(37 \%)$ of patients gave positive results for the urease A gene by PCR assay; 34 (31\%) of patients were positive by these three tests and $\mathrm{H}$. pylori was cultured from the gastric juice of $13(38 \%)$ of these patients. The median count of $H$. pylori in gastric juice was $1.75 \times 10^{1} \mathrm{cfu} / \mathrm{ml}$. Viable organisms in gastric juice may lead to transmission of $H$. pylori when refluxed or vomited into the mouth.
\end{abstract}

\section{Introduction}

Helicobacter pylori is an important aetiological factor for chronic gastritis and peptic ulcer disease, and is associated with gastric cancer and lymphoma [1-3]. Despite current understanding of the pathophysiology and virulence determinants of this important gastric pathogen, its mode of transmission and infectious dose remain uncertain [4]. Person-to-person spread is the most probable mode of transmission, as no environmental or zoonotic reservoirs have been established. Successful transmission requires that viable organisms are available, but culture of $H$. pylori from sites other than the gastric mucosa, such as the oral cavity and faeces, is rare $[5,6]$. The incidence of $H$. pylori at these sites has been investigated by PCR, providing inconclusive evidence for either oral-oral or faecaloral transmission in man [7-9].

H. pylori is readily passed from person to person by gastric intubation [10], which usually results in several weeks of acute infection. Gastric juice may play an important role in the natural route of transmission [11]

Received 6 May 1999; revised version accepted 26 Aug. 1999.

Corresponding author: Ms K. A. Young (e-mail: k.a.young@ mds.qmw.ac.uk). as gastritis, especially in the acute stage, is often accompanied by increased episodes of intermittent reflux [12] which may facilitate the passage of viable organisms into the mouth, from where they may be transmitted to other individuals. H. pylori DNA can easily be detected in the gastric juice of gastric biopsypositive individuals by PCR $[13,14]$, but detection of viable organisms in this fluid varies greatly [15-18]. The present study determined whether viable $H$. pylori were present in the gastric juice of adult patients with gastritis, and calculated the numbers of organisms available for transmission.

\section{Materials and methods}

\section{Study subjects and sample collection}

A total of 108 patients (67 male, 41 female; age 17-74 years, mean 46 years) attending the endoscopy unit of the Royal London Hospital, Whitechapel, East London for various reasons, was studied. Patients were chosen at random and ethical permission was obtained for participation in the study. Those patients who had previously received anti- $H$. pylori therapy or were taking acid-suppressing medication were excluded from the study. As much gastric juice as possible (0.5$15 \mathrm{ml}$, mean $8 \mathrm{ml}$ ) was aspirated from the fundic pool of each patient through the endoscope and collected via 
a sputum trap at the beginning of the endoscopy procedure. The $\mathrm{pH}$ of the gastric juice was measured with $\mathrm{pH}$ test strips (Sigma) and immediately neutralised with $0.67 \mathrm{M}$ Tris buffer ( $\mathrm{pH}$ 7.4) if necessary [19]. The original volume and appearance of the gastric juice were noted. One antral gastric biopsy was taken for the rapid urease test (RUT). Histological examination of one other formalin-fixed antral gastric biopsy stained with the standard haematoxylin and eosin stain was performed by a pathologist experienced in the detection of $H$. pylori. One antral gastric biopsy was collected for culture in $1 \mathrm{ml}$ of glucose $20 \% \mathrm{w} / \mathrm{v}$ from 100 of the patients.

\section{Bacterial culture from gastric juice and gastric biopsy samples}

Gastric juice samples from all 108 patients were centrifuged at $13000 \mathrm{rpm}$ in a microcentrifuge for $5 \mathrm{~min}$ at room temperature and each deposit was concentrated to a volume of $1 \mathrm{ml}$. Serial dilutions were made in Brain Heart Infusion (BHI) Broth (Oxoid CM225,) and 100- $\mu$ l volumes were cultured in duplicate on to non-selective BHI Agar (Oxoid CM375) containing defibrinated horse blood $5 \%$, and on to BHI agar containing $H$. pylori selective supplement (Oxoid SR147). All samples were processed within $2 \mathrm{~h}$ of collection. Plates were incubated micro-aerobically (Campylobacter gas generating kit, Oxoid BR60) at $37^{\circ} \mathrm{C}$ for 5 days. Suspected colonies of H. pylori were identified by Gram's stain and positive reactions for catalase, oxidase and urease [20]. Growth was quantified as $\mathrm{cfu} / \mathrm{ml}$ of gastric juice. The effect of $0.67 \mathrm{M}$ Tris buffer on the growth of $H$. pylori was assessed with National Collection of Type Cultures (NCTC) type strain 11637 . Serial dilutions of this strain were made $\left(10^{1}-10^{8} / \mathrm{ml}\right)$ in $0.67 \mathrm{M}$ Tris buffer and left at room temperature for $2 \mathrm{~h}$ before being cultured as above. H. pylori was cultured from all the concentrations tested. Gastric antral biopsies were homogenised and $100-\mu 1$ volumes were cultured in duplicate as for the gastric juice samples.

\section{PCR amplification from gastric juice}

Chromosomal DNA was extracted from the gastric juice of all 108 samples by the cetyltrimethylammonium bromide (CTAB) method according to the DNA miniprep protocol of Wilson [21]. This method is known to remove complex polysaccharides which may inhibit PCR amplification. The primers HPU1 and HPU2 were used to amplify a 411-bp internal fragment of the urease A gene of $H$. pylori as described previously [22]. This assay had been assessed previously for its specificity for the urease A gene of $H$. pylori and found not to cross-react with other Helicobacter species or known urease-producing oral organisms [7]. H. pylori NCTC 11637 which had been incubated in Tris buffer $(0.67 \mathrm{M})$ at room temperature for $2 \mathrm{~h}$ was also subjected to DNA extraction followed by PCR to determine the minimum detectable number of bacteria with this method. H. pylori was detected by PCR at all dilutions tested to a level of $10 \mathrm{cfu} / \mathrm{ml}$.

\section{Results}

Of the 108 patients evaluated, $54(50 \%)$ were infected with $H$. pylori as assessed by both the RUT and histology (Table 1). All patients who were H. pyloripositive by the RUT were also histology-positive, and vice versa. $H$. pylori was cultured from the gastric biopsies of $32(59 \%)$ of these 54 patients, but not from any patient who was RUT and histology negative. The gastric juice of 40 (37\%) of 108 patients was H. pylori PCR-positive (Fig. 1) of which 28 were cloudy in appearance with mucus and 12 contained bile. Only 34 (31\%) of 108 patients were H. pylori-positive at both sites, i.e., antral biopsy RUT- and histology- positive and gastric juice PCR-positive. This is explained by the observation that of those patients who were antral biopsy H. pylori-positive, $20(37 \%)$ of 54 were gastric

Table 1. Detection of $H$. pylori in 108 subjects by conventional biopsy-based tests, culture and PCR

\begin{tabular}{lcc}
\hline Method of detection (sample) & $\begin{array}{c}\text { Number } \\
\text { tested }\end{array}$ & $\begin{array}{c}\text { Number (\%) } \\
\text { positive }\end{array}$ \\
\hline RUT $^{*}$ (biopsy) & 108 & $54(50)$ \\
Histology* (biopsy) & 108 & $54(50)$ \\
PCR (GJ) & 108 & $40(37)$ \\
RUT, histology and PCR (biopsy & 108 & $34(31)^{\dagger}$ \\
$\quad$ and GJ) & $34^{\dagger}$ & $13(38)$ \\
Culture (GJ) &
\end{tabular}

RUT, rapid urease test; GJ, gastric juice.

*All biopsy samples that were RUT-positive were also histologypositive and vice versa.

${ }^{\dagger}$ Samples were positive by all three tests.

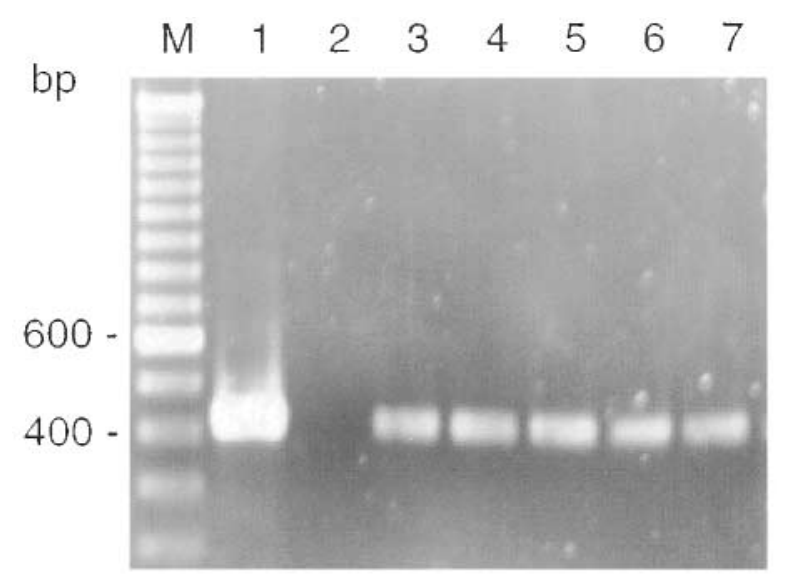

Fig. 1. Ethidium bromide-stained agarose $1 \%$ gel of PCRamplified 411-bp products obtained with primers HPU1 and HPU2, specific for the urease A gene of $H$. pylori. Lanes: M, 100-bp DNA ladder (Life Technologies, Paisley); 1, H. pylori NCTC 11637, positive control showing 411-bp product; 2, water (negative control); 37, various gastric juice samples all showing 411-bp product. 
juice PCR-negative, and of those patients who were gastric juice PCR-positive, 6 (15\%) of 40 were antral biopsy-negative by both RUT and histology. Hence, individual analysis of all 108 patients showed that only 34 were $H$. pylori-positive at both sites.

H. pylori was cultured from the gastric juice of 13 $(38 \%)$ of those 34 patients who were H. pylori positive at both sites as described above (Table 2). All 13 of these gastric juice samples were cloudy in appearance with mucus and initially had a $\mathrm{pH}$ of $1-2$, except one from a 32-year-old female, which had a $\mathrm{pH}$ of 8 . This sample contained $8 \times 10^{1} \mathrm{cfu}$ of $H$. pylori $/ \mathrm{ml}$. Colony counts ranged from 1 colony in $15 \mathrm{ml}$ to $3.6 \times$ $10^{3} \mathrm{cfu} / \mathrm{ml}$ of gastric juice (median $1.75 \times$ $10^{1} \mathrm{cfu} / \mathrm{ml}$ ) in these 13 culture-positive samples. $H$. pylori was not cultured from samples containing bile. There was no apparent association between culture of H. pylori from gastric juice and disease in these 13 patients (Table 2). H. pylori was also cultured from the gastric biopsies of these 13 patients, but the growth was not quantified. H. pylori was not cultured from the gastric juice of any patient who was either antral biopsy RUT- or histology-negative, or gastric juice PCR-negative. H. pylori was not cultured from the gastric biopsy of any patient sampled who was RUTand histology-negative, but was cultured from 12 gastric juice PCR-positive and 7 gastric juice PCRnegative patients, in addition to the 13 patients who were gastric juice culture-positive.

\section{Discussion}

H. pylori was cultured from the gastric juice of $38 \%$ of infected individuals as determined by RUT and histology of antral biopsy and PCR of gastric juice. Previous studies report a wide range $(0-67 \%)$ of successful culture of $H$. pylori from gastric juice of infected subjects [15-18], but none has attempted to quantify the numbers of organisms present. The results of the present study indicate that a detectable number (median $1.75 \times 10^{1} \mathrm{cfu} / \mathrm{ml}$ ) of viable $H$. pylori can be cultured from gastric juice. The density of $H$. pylori in gastric antral biopsies has been calculated as $10^{5}-$ $10^{6} \mathrm{cfu} / \mathrm{g}$ [23]. However, this quantity will vary depending on the severity of infection, and not all organisms will remain viable when shed into gastric juice. The infectious dose of $H$. pylori remains unknown, as data from three volunteer experiments are inconclusive. Marshall [24] achieved successful infection with a recently isolated field strain at a dose of $10^{9}$ organisms in a small liquid feed following the use of antacids. A second volunteer failed to become infected [25] with a dose of $4 \times 10^{7}$ organisms of the same field strain after an overnight fast. Infection did succeed in the second volunteer [26] when antacids were used with a different field strain at a dose of $3 \times 10^{5}$ organisms. However, these experimental doses may be in excess of the numbers of organisms required to cause natural infection.

Reports of unsuccessful attempts to culture $H$. pylori from the mouth $[27,28]$ may be due to the organism being present in a non-culturable coccoid form, or as a transient member of the oral microflora. However, detection by PCR indicates that the presence of $H$. pylori can be demonstrated in the mouths of a significant number of infected individuals [7,8]. If intermittent gastro-oesophageal reflux is responsible for delivery of $H$. pylori into the mouth, this may account for the variability between studies investigating the detection of the organism by culture and PCR. Iatrogenic transmission has shown how readily the organism can be passed from patient to patient by gastric secretions which stick to the surfaces of an endoscope [10]. If reflux of gastric contents is important for transmission, the time during which this can successfully take place may be limited to immediately after an episode of reflux, when viable organisms are most likely to be present. Gastrooesophageal reflux disease (GORD) is often found in patients with antral gastritis, but there are no data to show that these patients are infected with $H$. pylori

Table 2. Details of patients and gastric juice samples from which H. pylori was cultured

\begin{tabular}{lccccll}
\hline Study no. & Sex & Age (years) & GJ volume $(\mathrm{ml})^{*}$ & GJ $\mathrm{pH}$ & $\mathrm{cfu} / \mathrm{ml}$ in GJ & Endoscopy diagnosis \\
\hline 1 & $\mathrm{M}$ & 66 & 10 & 1 & 9.8 & $\mathrm{G}$ \\
2 & $\mathrm{M}$ & 65 & 10 & 1 & 3.9 & $\mathrm{HH}+\mathrm{G}$ \\
3 & $\mathrm{M}$ & 58 & 10 & 2 & $6 \times 10^{1}$ & $\mathrm{G}$ \\
4 & $\mathrm{~F}$ & 39 & 10 & 1 & $9.4 \times 10^{1}$ & $\mathrm{G}$ \\
5 & $\mathrm{~F}$ & 54 & 15 & 2 & $1.52 \times 10^{2}$ & $\mathrm{DU}$ \\
6 & $\mathrm{M}$ & 36 & 12 & 1 & $1.08 \times 10^{1}$ & $\mathrm{G}$ \\
7 & $\mathrm{M}$ & 76 & 15 & 2 & 1 in total & $\mathrm{HH}+\mathrm{G}$ \\
8 & $\mathrm{M}$ & 54 & 15 & 2 & $3.6 \times 10^{3}$ & $\mathrm{G}$ \\
9 & $\mathrm{M}$ & 55 & 10 & 1 & 5.14 & $\mathrm{DU}$ \\
10 & $\mathrm{~F}$ & 70 & 10 & 1 & $3.48 \times 10^{1}$ & $\mathrm{DU}$ \\
11 & $\mathrm{~F}$ & 32 & 10 & 1 & $8 \times 10^{1}$ & $\mathrm{G}$ \\
12 & $\mathrm{M}$ & 39 & 10 & 2 & 1.22 & $\mathrm{G}$ \\
13 & $\mathrm{~F}$ & 59 & & & $\mathrm{G}$ \\
\hline
\end{tabular}

GJ, gastric juice; G, gastritis; DU, duodenal ulcer; HH, hiatus hernia.

* All gastric juice samples were cloudy in appearance with mucus. 
more frequently than controls, either in adults or children [29]. In contrast, epidemiological data tend to support the hypothesis that H. pylori infection may give some protection against reflux disease and adenocarcinoma of the gastro-oesophageal junction [30].

Acute gastritis is often accompanied by a period of temporary hypochlorhydria or achlorhydria [12], which may favour survival of $H$. pylori in gastric juice. In the present study this state was observed in only one of the patients with antral gastritis in whom the gastric juice $\mathrm{pH}$ was 8 , and $8 \times 10^{1} \mathrm{cfu}$ of $H$. pylori $/ \mathrm{ml}$ were isolated. Furthermore, there was no correlation between disease state and those patients from whom $H$. pylori in gastric juice was successfully cultured.

Culture of H. pylori from faeces has been achieved [6]. This is surprising, as bile is bactericidal to this organism $[20,31]$. H. pylori which is shed into gastric juice would not normally survive transit through the intestinal tract because of the toxic effect of bile in the second part of the duodenum. The results of Thomas et al. [6] may be explained by their selection of patients, who were all children with acute gastritis and reduced gastric acid secretion. If transmission of $H$. pylori via faeces does occur then it may be restricted to hypochlorhydric or achlorhydric individuals with acute infection.

It has been suggested that a gastric juice-based PCR assay may be a good alternative to conventional biopsy-based detection techniques [14,32]. However, the present study showed that $30 \%$ of patients with positive biopsy results had negative results in PCR assays of gastric juice. Many patients had a very small volume of fluid in their stomach which was difficult to collect and may have contained numbers of organisms not detectable by the PCR assay employed.

Acquisition of $H$. pylori occurs predominantly in childhood [33], but it is not clear whether transmission takes place primarily between adults and children or from child to child. Although this study was concerned with adult patients, the results suggest that children may also have the potential to spread $H$. pylori via the mouth. It is possible that the numbers of organisms in gastric juice during a first infection, which is more common in children [33], are greater than those found in persons with a chronic infection. Further studies in children would clarify this question.

In conclusion, these results demonstrate that viable $H$. pylori are present in gastric juice for potential transmission via the mouth. Further study of the infectious dose of the organism is required to clarify the significance of this potential.

We thank P. A. Williams for helping to recruit the patients and R. M. Feakins for the histopathology analysis.

\section{References}

1. Blaser MJ, Chyou PH, Nomura A. Age at establishment of Helicobacter pylori infection and gastric carcinoma, gastric ulcer, and duodenal ulcer risk. Cancer Res 1995; 55: 562-565.

2. The Eurogast Study Group. An international association between Helicobacter pylori infection and gastric cancer. Lancet 1993; 341: 1359-1362.

3. NIH Consensus Development Panel on Helicobacter pylori in Peptic Ulcer Disease. Helicobacter pylori in peptic ulcer disease. JAMA 1994; 272: 65-69.

4. Feldman RA, Eccersley AJP, Hardie JM. Epidemiology of Helicobacter pylori: acquisition, transmission, population prevalence and disease-to-infection ratio. Br Med Bull 1998; 54: 39-53.

5. Krajden S, Fuksa M, Anderson J et al. Examination of human stomach biopsies, saliva, and dental plaque for Campylobacter pylori. J Clin Microbiol 1989; 27: 1397-1398.

6. Thomas JE, Gibson GR, Darboe MK, Dale A, Weaver LT. Isolation of Helicobacter pylori from human faeces. Lancet 1992; 340: 1194-1195.

7. Banatvala N. Romero Lopez C, Owen RJ et al. Use of the polymerase chain reaction to detect Helicobacter pylori in the dental plaque of healthy and symptomatic individuals. Microb Ecol Health Dis 1994; 7: 1-8.

8. Li C, Musich PR, Ha T et al. High prevalence of Helicobacter pylori in saliva demonstrated by a novel PCR assay. $J$ Clin Pathol 1995; 48: 662-666.

9. Mapstone NP, Lewis FA, Tompkins DS et al. PCR identification of Helicobacter pylori in faeces from gastritis patients. Lancet 1993; 341: 447.

10. Tytgat GNJ. Endoscopic transmission of Helicobacter pylori. Aliment Pharmacol Ther 1995; 9 Suppl 2: 105-110.

11. Axon ATR. Review article: is Helicobacter pylori transmitted by the gastro-oral route? Aliment Pharmacol Ther 1995; 9: 585-588.

12. Axon ATR. Acute infection with H. pylori. In: Hunt RH, Tytgat GNJ (eds) Helicobacter pylori. Basic mechanisms to clinical cure. Dordrecht, Kluwer Academic Publishers. 1996: 407-412.

13. Shimada $\mathrm{T}$, Ogura $\mathrm{K}$, Ota $\mathrm{S}$ et al. Identification of Helicobacter pylori in gastric specimens, gastric juice, saliva, and faeces of Japanese patients. Lancet 1994; 343: 16361637.

14. Yoshida H, Hirota K, Shiratori Y et al. Use of gastric juicebased PCR assay to detect Helicobacter pylori infection in culture-negative patients. J Clin Microbiol 1998; 36: 317-320.

15. Andersen LP, Elsborg L, Justesen T. Campylobacter pylori in peptic ulcer disease. II. Endoscopic findings and cultivation of C. pylori. Scand J Gastroenterol 1988; 23: 760-764.

16. Galal G, Wharburton V, West A et al. Isolation of H. pylori from gastric juice. Gut 1997; 41 Suppl 1: A40 (abstract $03 / 150)$.

17. Okuda M, Tanaka T, Nakamoto $\mathrm{H}$ et al. Helicobacter pylori infection in childhood: H. pylori isolation rate in gastric juice in relation to positive serum antibody rates. $J$ Gastroenterol 1996; 31 Suppl IX: 6-8.

18. Varoli O, Landini MP, Laplace $\mathrm{M}$ et al. Presence of Helicobacter pylori in gastric juice. Am J Gastroenterol 1991; 86: 249.

19. Westblom TU, Phadnis S, Yang P, Czinn SJ. Diagnosis of Helicobacter pylori infection by means of a polymerase chain reaction assay for gastric juice aspirates. Clin Infect Dis 1993; 16: $367-371$.

20. Goodwin CS, Armstrong JA, Chilvers $\mathrm{T}$ et al. Transfer of Campylobacter pylori and Campylobacter mustelae to Helicobacter gen. nov. as Helicobacter pylori comb. nov. and Helicobacter mustelae comb. nov., respectively. Int J Syst Bacteriol 1989; 39: 397-405.

21. Wilson K. Preparation of genomic DNA from bacteria. In: Ausubel FM, Brent R, Kingston RE (eds) Current protocols in molecular biology. Chichester, Wiley. 1987.

22. Clayton CL, Kleanthous H, Coates PJ, Morgan DD, Tabaqchali S. Sensitive detection of Helicobacter pylori by using polymerase chain reaction. J Clin Microbiol 1992; 30: 192-200.

23. Atherton JC, Tham KT, Peek RM, Cover TL, Blaser MJ. Density of Helicobacter pylori infection in vivo as assessed by quantitative culture and histology. J Infect Dis 1996; 174: $552-556$. 
24. Marshall BJ, Armstrong JA, McGechie DB, Glancy RJ. Attempt to fulfil Koch's postulates for pyloric Campylobacter. Med J Aust 1985; 142: 436-439.

25. Morris A, Nicholson G. Ingestion of Campylobacter pyloridis causes gastritis and raised fasting gastric pH. Am J Gastroenterol 1987; 82: 192-199.

26. Morris AJ, Ali MR, Nicholson GI, Perez-Perez GI, Blaser MJ. Long-term follow-up of voluntary ingestion of Helicobacter pylori. Ann Intern Med 1991; 114: 662-663.

27. Bernander S, Dalen J, Gastrin B, Hedenborg L, Lamke LO, Ohrn R. Absence of Helicobacter pylori in dental plaques in Helicobacter pylori positive dyspeptic patients. Eur J Clin Microbiol Infect Dis 1993; 12: 282-285.

28. Luman W, Alkout AM, Blackwell CC, Weir DM, Palmer KR. Helicobacter pylori in the mouth - negative isolation from dental plaque and saliva. Eur J Gastroenterol Hepatol 1996; 8: $11-14$

29. Tytgat GNJ. Role of Helicobacter pylori infection in gastro- oesophageal reflux disease. In: Hunt RH, Tytgat GNT (eds) Helicobacter pylori. Basic mechanisms to clinical cure. Dordrecht, Kluwer Academic Publishers. 1996: 304-311.

30. Labenz J, Malfertheiner P. Helicobacter pylori in gastrooesophageal reflux disease: causal agent, independent or protective factor? Gut 1997; 41: 277-280.

31. Mitchell HM, Li $\mathrm{Y}, \mathrm{Hu} \mathrm{P}$ et al. The susceptibility of Helicobacter pylori to bile may be an obstacle to faecal transmission. Eur J Gastroenterol Hepatol 1992; 4 Suppl 1: S79-S83.

32. Basso D, Navaglia F, Cassaro $\mathrm{M}$ et al. Gastric juice polymerase chain reaction: an alternative to histology in the diagnosis of Helicobacter pylori infection. Helicobacter 1996; 1: $159-164$

33. Taylor DN, Parsonnet J. Epidemiology and natural history of H. pylori infections. In: Blaser MJ, Smith PF, Ravdin J, Greenberg H, Guerrant RL (eds) Infections of the gastrointestinal tract. New York, Raven Press. 1995: 551-564. 